\title{
ISLAMIC REFORM MOVEMENT IN INDONESIA AND BEYOND Progress and Regress
}

\author{
Luthfi Assyaukanie \\ Paramadina University, Jakarta, Indonesia
}

\begin{abstract}
This paper is an attempt to review the Islamic reform agendas that have been set by Muslims reformists since the last century. Islamic reform movement has developed and spread from the Middle East to many Muslim countries in the world. Indonesia where Muslims represent the largest population enthusiastically welcomes such a movement. From Minangkabau in West Sumatra, Islamic reform movement then spreads into other areas in the country. It deals with issues that baffled modern Muslims, such as democracy, freedom, pluralism, and secularism. There are some progress and regress in how Muslims respond to those issues. In this article, I address four issues Muslim reformists discussed throughout the decades, namely: Islamic polity, women's rights, religious freedom, and freedom of expression.
\end{abstract}

Keywords: Islamic reform, Islamic modernism, Islamic liberalism.

\section{Introduction}

Islamic reform movement is an intellectual activity that brings a new understanding of the classical Islamic doctrines in line with the spirit of the age. As a scholarly activity, Islamic reform has been undertaken since a long time. However, as a social movement, it has just begun two centuries ago. Scholars such as Albert Hourani and Bernard Lewis consider the Napoleon Bonaparte's invasion to Egypt in 1798 as the beginning of the Islamic reform movement in the 
modern times. ${ }^{1}$ Lewis regards it as a watershed and "the first shock to Islamic complacency, the first impulse to westernization and reform."'2 The Bonaparte's invasion to Egypt was important both for Muslims as well as for the Western people. For Muslims, it has resuscitated them that the modern military of the Europeans could easily defeat the heartland of Islam. For the Europeans, the invasion has opened their eyes that Islam is no longer a powerful civilization as it was in the past.

Bonaparte's invasion has marked a great impact for the future of Egyptian people. The inroad was not only a military accomplishment, but, as al-Jabarti, the greatest Egyptian historian in the early modern times, noted, it has drawn a deep impact for the social, cultural, political, and scientific aspects of Muslim life. ${ }^{3}$ Apart from military forces, Bonaparte brought with him a team of scientists, printing machine, medical tools, and a set of modern laws. Although he ruled Egypt for only three years, he has paved the way for a long way of modernization of the country. ${ }^{4}$ France's short occupation has inspired the rulers of modern Egypt to catch up with modern world, where Europe became its role model. The first Egyptian ruler, Muhłmmad Ali>sent a delegacy of students to France. It was the biggest mission that a Muslim ruler ever did. The mission itself, led by Rifa al$\mathrm{T}\{\mathrm{h}\} \mathrm{f}+\mathrm{i} \ngtr \mathrm{d}$. 1873), was a significant mark for the history of Islamic reform movement in the modern times.

From Egypt, the Islamic reform movement spread to other Islamic countries. Al-T $\{\mathrm{h}\} \mathrm{f}+\mathrm{j}>\mathrm{i}>$ inherited many disciples and followers, among them was Muhłmmad `Abduh (d. 1905), the greatest Muslim reformist in the modern times. Muslims from the Southeast Asia were among those influenced by the Egyptian reform movement. ${ }^{5}$ In the dawn of the twentieth century, Muhammad Taher Djalaluddin (d. 1956), an

\footnotetext{
1 Albert Hourani, Arabic Thought in the Liberal Age, 1798-1939 (Cambridge, New York: Cambridge University Press, 1983); Bernard Lewis, The Middle East and the West (Bloomington: Indiana University Press, 1964).

${ }^{2}$ Lewis, The Middle East and the West, p. 34.

3 'Abd al-Rahina al-Jabarti>'Aja al-A Lajnat al-Bayałal-'Arabi $>1958)$.

${ }^{4}$ P. J. Vatikiotis, The History of Modern Egypt: From Mubammad Ali to Mubarak, $4^{\text {th }}$ ed. (Baltimore: Johns Hopkins University Press, 1991).

5 Hamka, Ajabku, Riwajat Hidup Dr. H. Abd. Karim Amrullah dan Perdjuangan Kaum Agama di Sumatra, 2nd ed. (Djakarta: Widjaya, 1958).
} 
Indonesian student in Cairo, set his foot in Singapore. He studied with 'Abduh and established a good relationship with Rashi Rid $>>$ d. 1935). He learnt from these two towering figures how to write Islamic issues in a journalistic style. Later in 1906, he published a periodical called al-Imam, the first Islamic magazine in the Malay world that resonated 'Abduh's reformist ideas. Djalaluddin and other MiddleEastern graduates such as Abdullah Ahmad (d. 1933) Muhammad Djamil Djambek (d. 1947), and Hadji Rasul (d. 1945), were later recorded as the early proponents of Islamic reform movement in Indonesia and the Malay world. ${ }^{6}$

Since its inception, Islamic reform movement has a liberal character in the sense that renaissance (nabdobs) and the idea of progress became its main theme. The early Muslim reformists asked this kind of questions: what are the requirements of renaissance (ma Aiya shurufalnabdah?); how do Muslims lag behind and how does the West progress

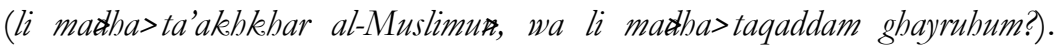
Answers to these questions created a new discourse of Islamic thought, which is subsequently labeled in various terms such as "Islamic modernism," "Islamic reform," "progressive Islam," and "Islamic liberalism."

This paper is an attempt to review the Islamic reform ideas that have been discussed by the Muslims reformist throughout the ages and how do Muslims respond to those ideas. I will focus on the reform agendas that the Muslim reformists have been successful and the one that they have failed. Islamic reform is a global phenomenon that it is impossible to cover all of its areas. I will therefore focus only on the Southeast Asia and the Middle East by providing cases from Indonesia and Egypt as an example.

\section{Reformist Agendas}

Islamic reform movement has a multitude agenda, which is very much dependant on its social and political context. In the nineteenth century, when Muslims felt so much in backward, the main discourse developed was the idea and the model of progress. Modern science

\footnotetext{
6 See Deliar Noer, The Modernist Muslim Movement in Indonesia, 1900-1942, East Asian Historical Monographs (New York: Oxford University Press, 1973); William R. Roff, The Origins of Malay Nationalism (New Haven: Yale University Press, 1967); Michael Francis Laffan, Islamic Nationhood and Colonial Indonesia: The Umma Below the Winds (New York: RoutledgeCurzon, 2003).
} 
and technology as well as the golden age of Islam in the classical times were often mentioned with esteem. Al-Tah on Paris, where he described the triumphant of modern Europeans over science and technology. Likewise, Ami $\gg$ Sha Arsla $\gg$ wrote a book on why Muslims lag behind and why the Western people progressed? One of the answers that Arslaæaddressed was the lack of education among Muslims. Qassim Amiæ, another Egyptian intellectual, pointed out a bad treatment of Muslims towards their woman. Ami believed that woman (i.e. mother) is the first school (madrasat al-ufor Muslim children. The quality of future generation is very much determined by the first school that they experienced (I will elaborate on this issue below).

Prior to the end of the Second World War, issues such as colonialism, nationalism, socialism, and capitalism were quite dominant among Muslim intellectuals. In the Arab world, the issue of

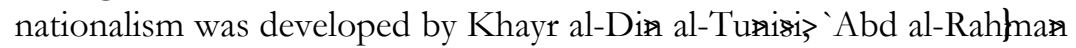
al-Kawabizand Ahthad Lut Sayyid, while in the Southeast Asia, the issue was enthusiastically discussed by such intellectuals as Tjokroaminoto, Agus Salim, and Soekarno. After independence, Muslim reformists dealt with new issues such as the basis of the state, constitutional law, democracy, and human rights. After the 1970s, other issues such as gender equality, religious freedom, civil liberty, and freedom of expression, occupied Muslim mind. With the rise of Islamic radicalism in Egypt and other Muslim countries, religious fundamentalism and conservatism have also become the concern of Muslim reformists.

Charles Kurzman, the author of well-acclaimed book Liberal Islam, counted several issues discussed by the Muslim reformists throughout the ages and categorized them into six main agendas, namely against theocracy, democracy, the rights of women, the rights of non-Muslims, freedom of thought, and the idea of progress. ${ }^{7}$ Following Kurzman's categorization, in this paper, I would like to classify problems discussed in the current Islamic reform movement into four main issues: Islamic polity, women's rights, religious freedom, and freedom of expression. I will discuss each of these issues in separate sections.

${ }^{7}$ Charles Kurzman, Liberal Islam: A Source Book (New York: Oxford University Press, 1998). 


\section{Islamic Polity}

The relationship between Islam and the state is a perennial question that has emerged since the second quarter of the twentieth century. Although the issue itself has been discussed in the classical discipline of Islamic jurisprudence known as fiqh al-siyasth (political philosophy), the modern treatment of the problem took place just in the twentieth century. It all began with the crisis of the caliphate in Turkey in 1924. On 3 March 1924, Mustafa Kamal Ataturk, the founder of the modern Turkey, abolished the caliphate system, ending the long dominant system of the Ottoman Empire. Ataturk's move was subsequently responded by Muslims all over the world. In 1919, a group of Muslims in India founded an association called the Caliphate Movement, a political group that called for the restoration of the caliphate. In Egypt and Hejaz, the crisis over the caliphate was responded by conducting a caliphate conference held in Cairo and Jeddah. This call was later responded by many Muslim leaders from various countries. Indonesian Muslims sent two delegations for the conference: one to Jeddah, led by Tjokroaminoto, the leader of Sarekat Islam, and the other to Cairo, led by Abdul Karim Amrullah, a wellknown Muslim reformist from Sumatra.

Apart from the political responses, the issue of the caliphate was also responded intellectually. The intellectual responses had actually begun several years before the caliphate was formally closed by

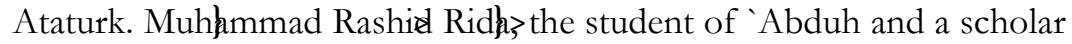
of Egyptian al-Azhar, wrote a series of articles on caliphate in al-Manar, a magazine he edited. The article was later published as a book under the title al-Imarah wa al-Khilath al- Uzha the Imamate and the Great Caliphate). The main idea that Rid ł zried to deliver was that caliphate is a religious obligation that modern Muslims must maintain. Quoting the

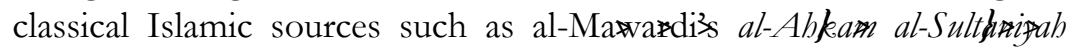
and Ibn Taymizah's al-Siymah al-Shar ijwh, Ridłargued that caliphate is an Islamic political system inspired by the Qur'aæand the Prophetic tradition (sunnab). All Muslims are obliged to uphold the system and must try their best to fight against its abolition. Rid $\$$ argument was soon rebutted by his colleague, 'Ali 'Abd al-Raziq, also a student of 'Abduh and graduate of al-Azhar, in his masterpiece, al-Isla wa Niq al-Horkm (Islam and the Government System). 'Abd al-Raæiq argued that caliphate is not a political system required deliberately by Islam. 
The Prophet Muhłmmad was sent by God as a messenger and not as a political leader, let alone a head of state. Islam does not prescribe Muslims to build certain form of government. In fact, the form of government is entirely designated to Muslim's reasoning (ijtibalt.

The debate between Ridłand 'Abd al-Ra political attitude over the issue of caliphate. Muslims were broadly divided into two factions: the opponents and the proponents. Most of secular Muslims (namely those who do not come from the religious background) would likely reject the idea of caliphate that they would go with ‘Abd al-Raæiq's argument. Meanwhile, Muslims who come from the religious background, particularly those who had a strong affiliation with Islamic institutions, would likely support RashiæRidłs. In the Arab world, 'Abd al-Raæiq's view was supported by the

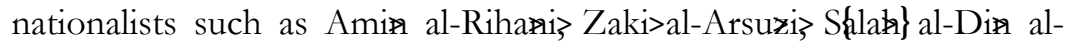
Bitar, and Sa al-Husri> In Indonesia, secular leaders such as Soekarno and Soepomo often quoted 'Abd al-Raßq's book to endorse their opposition to the idea of the Islamic state pioneered by the Islamists. It was quite uncommon to find Muslims from a religious background supporting 'Abd al-Raæi idea. What was common rather the opposite, namely, they would entirely denounce 'Abd alRaæiq as un-Islamic or at least a Muslim who has deviated from the "true" Islam. This is why throughout the modern history of Islamic political discourse, ‘Abd al-Raæiq's name has been extremely notorious among Islamic circles.

It was only time that proved 'Abd al-Rałà's quality that he was more desirable among Muslims than that of Rashid Rid Half a century later, none of Muslim rulers would adopt caliphate as a system of government. Even the most ardent candidates, Egypt and Saudi Arabia, preferred to choose "nation-state" as the platform of the state. Under Gamal Abd al-Nasser, Egypt was transformed from monarchy into democracy. Saudi Arabia, since the outset, declared herself as an "Islamic kingdom," a new vocabulary in Islamic political thought. Rather than obsessed with the global imperia, the Saudi monarch stuck

\footnotetext{
8See their biography in Fahmi Jadan's books, Ususal-Taqaddum 'inda Mufakkir al-Islam fi

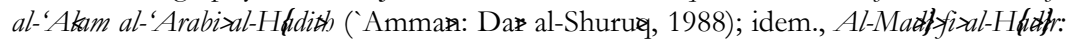
Dira $>$ fi $>$ Tashakekula $\gg$ wa Masa al-Tajrimh al-Fikrizah al-'Arabizh (Beirut: alMu'assasah al-`Arabipah li al-Dirasatæwa al-Nashr, 1997).
} 
to the Hejaz, excluding the most part of Muslim lands. Rid argument of caliphate was modified by some of his followers and sympathizers. Instead of promoting Islamic caliphate, they introduced

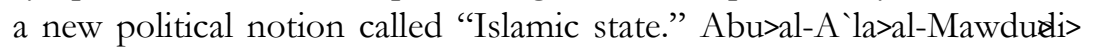
of Pakistan and Sayyid Qut\} of Egypt were among the proponents of this idea. In Indonesia, the idea of Islamic state was supported by santri Muslims affiliated to the Masyumi Party. Islamic State, as Enayat rightly explains, is the only feasible alternative for the crumbled system of the caliphate. ${ }^{9}$

Since the end of the Second World War, a few Muslim communities tried their luck to adopt Islam as a basis of state and government. Pakistan, Sudan, and Iran were among those rare countries to undertake this experience. The rest of the Muslim world prefers to be a democratic system, where people's sovereignty determines the political system. Even for Muslim countries where Islam is officially recognized as the state's religion, such as Malaysia, the entire system of government is close to democracy rather than to theocracy. Islamic state in a theocratic style, as precisely defined by alMawduland Qut\}, has never been attracting many Muslims outside the countries mentioned above. Even in those countries, such as Pakistan and Iran, the theocratic style of Islamic state, has been severely contested. ${ }^{10}$

Certainly, there are reasons why the idea of Islamic state does not attract many Muslims. First, it is theoretically not convincing. As Ahmed explains, intellectual Muslims in Pakistan never reached any consensus what did they mean by the Islamic state. There are at least four opinions regarding the idea, stretching from the very literal version to the extreme liberal ones. ${ }^{11}$ Second, none of the Islamic state has demonstrated a good example for a successful system of polity; neither Saudi Arabia nor Iran; neither Pakistan nor Sudan. Even a conservative Muslim would likely argue that those countries have

\footnotetext{
9 Hamid Enayat, Modern Islamic Political Thought (Kuala Lumpur: Islamic Book Trust, 2004), p. 104.

${ }^{10}$ Ishtiaq Ahmed, The Concept of an Islamic State: An Analysis of the Ideological Controversy in Pakistan (London: Pinter, 1987); Abdolkarim Soroush, Reason, Freedom, and Democracy in Islam: Essential Writings of Abdolkarim Soroush (New York, N.Y: Oxford University Press, 2000).

11 Ahmed, The Concept of an Islamic State, pp. 31-37.
} 
mistakenly implemented the idea of Islamic state. Abu Hanifah, a member of Masyumi and an Indonesian exponent of Islamic state preferred Switzerland or Netherlands as a good model of Islamic state, rather than Saudi Arabia or Pakistan. For him, Switzerland is closer to the spirit of Islamic polity than those countries that formally adopt Islam as the basis of state. ${ }^{12}$

In the present times, more and more Muslims denounced the idea of Islamic state. Even the radicals try to avoid using the term. In 2000, Forum Umat Islam, an association of the radical Islamic groups led by Abu Bakar Baashir, made an open statement that the idea of Islamic state is no longer visible for Indonesian Muslims. The Muslims in Indonesia, they argue, should not strive to establish an Islamic state. ${ }^{13}$ This statement might be political, but the fact that the most radical figures in Indonesia denounced their old ideal means that Islamic state is no longer a spellbinding idea. Only obstinate Muslims would still maintain the idea. Among them are members of the Hizbut Tahrir Indonesia (HTI), a radical organization that strives to return the clock back by reviving the idea of Islamic caliphate. HTI was founded by students who generally have a poor understanding of Islam and Islamic history. They come from secular universities who had no training in Islamic sciences. Its leader, Ismail Yusanto, is a graduate of Geology of the Gajah Mada University (UGM). Many of HTI members are students of secular universities such as UGM, IPB (Bogor Institute of Agriculture), and UI (the University of Indonesia). The biggest Islamic organization, Nahdlatul Ulama, has officially denounced HTI's maneuver as endangering the Indonesian Republic (NKRI).

\section{Women's Rights}

Discourse on the rights of women has been started since the late nineteenth century. Any historian of Islamic thought must mention Qassim Amiæ (d. 1908), an Egyptian intellectual and the disciple of Abduh, as the precursor of Islamic feminism. Ami was not the first author discussing the problem of women in the Muslim world. Some Muslim feminists such as Aicha Ismat al-Taymuriyya (d. 1902) and Zaynab Fawwaz (d. 1914), had preceded him. What makes Amiæ

12 Abu Hanifah, Kedudukan Agama dalam Negara-Negara Modern dan Merdeka (Jogjakarta: Kementerian Agama R.I., 1948), p. 20.

${ }^{13}$ Kompas, 06/08/2000; Panjimas, 9-16/08/2000; Tekad, 7-13/08/2000. 
important and was often considered as the father of Islamic feminism is because he was the first Muslim intellectual who systematically discussed the problem of Muslim women. Moreover, unlike his predecessor, Ami is a religious scholar and a graduate of al-Azhar. Ami wrote two books on Muslim woman, first on the liberation of

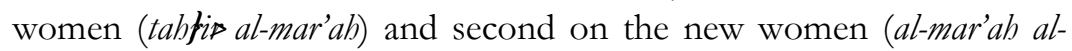
jadi h). The first book arouses more vibe than the latter. But for most of the conservative Muslims, both of the books are just nightmare.

In both books, Ami discusses the condition of Muslim women in Egypt whom he considered to have suffered from a bad patriarchal system. Amiædoes not blame Islam for this unfortunate condition but rather the Muslims who have mistakenly understood their religion. Like many other Muslim reformists, Amiæ considers Islam to be a perfect religion only that some of its teachings have been wrongly interpreted by its followers. In the first book, Ami examines some of Islamic doctrines that highly esteem woman's status. In many of Qur'anic verses, Ami argues, women are mentioned equally side by side with men. True that there are some verses that seem to suggest woman inequality, but, he argues, that this kind of verses have to be seen in its social and historical contexts. He gives the verse on polygamy (Q.S. 4:3) as an example. This verse, if read properly, is actually an order to avoid polygamy, a practice that was very common in the pre-Islamic era. Ami argues that Muslims often stop in the first part of the verse while ignoring the rest, which clearly indicates that "men will not become just." For Amiæ, polygamy is a pre-Islamic practice that was to be changed by Islam, and not the other way around.

Polygamy is not the centre of Ami concern, indeed. It is only part of the problems. What becomes his main concern is women's education and their involvement in public life. Ami argues that education is the heart of the problem and as far as women are concerned, they should be given priority. The argument is as follow: as woman will become mother for our future generation, she will become

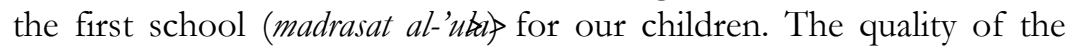
future generation very much depends on the quality of the first school. The educated mother would likely give a better education to her children than that of the uneducated one. Moreover, education for women is important as it will make them independent. With their 
education, Muslim women can earn their own living so that they could secure their independence and dignity before their husband. Education also could bring Muslim women to be actively engaged in public life either for work or other activities. Hence, Ami touches the crucial issues that involve Islamic doctrines on women such as women's seclusion, women's protector (mahram), the veil (bifals, and code of decency (awrab). In general, Ami view on these issues is liberal in the sense that he does not uncritically accept the classical opinions. He seems to be fully aware that one has to go beyond the classical understanding if he or she wants to really liberate Muslim women. For this and other reasons that Ami clearly singles out the Western system of society to be much better - and thus deserves to be emulated- than that of the Eastern one (i.e. Muslim community). He writes:

Look at the eastern countries; you will find woman enslaved to man and man to the ruler. Man is an oppressor in his home, oppressed as soon as he leaves it. Then look at the European countries; the governments are based on freedom and respect for personal rights, and the status of women has been raised to a high degree of respect and freedom of thought and action. ${ }^{14}$

Amiæs daring views are crucial in invigorating the Islamic discourse on women's rights. His Islamic approach to the issue has paved the way for theologians, scholars, and Muslim feminists to develop new arguments for empowering the status and role of Muslim women in the modern age. In Egypt, the Islamic discourse of women emerged quite widely and was articulated in various expressions; in book, articles, novels, cinemas, lectures, talk shows, and art works.

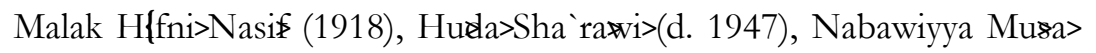
(1951), and Saiza Nabara $\ngtr$ 1985) represented the first generation of Egyptian feminists (or the second generation of the Arab feminists) who were strongly influenced by Amiæs works. In 1986, an alliance of several feminist groups in Egypt founded a magazine called al-Mar'ah al-jadich (the New Woman). The name was undoubtedly inspired by Ami book. Despite criticism and condemnation from the conservative 'ulama the discourse of Islamic feminism is rolling out as fast as the snow-ball.

${ }^{14}$ Hourani, Arabic Thought in the Liberal Age, p. 168. 
In Indonesia, the feminist discourse is not only managed by the secularists, but also by Muslim figures from religious background. In 2000, an Islamic non-government organization (NGO) called Rahima was founded by, among others, Husein Muhammad, a religious cleric (kiai) who runs an Islamic boarding school (pesantren) in Cirebon, West Java. The organization was designed as a centre for training and information on women's rights. Several months later, another NGO called Puan Amal Hayati was founded by Sinta Nuriya, the wife of the former president Abdurrahman Wahid. It focuses on advocating women's rights, particularly from a new Islamic perspective. In 2003, Puan Amal Hayati run a daring project criticizing classical Islamic books - known in Indonesia as "kitab kuning" ("yellow books")- that contain discriminative views on women. Among the books is 'UqualLujayn, a widely-read textbook written by Nawawi al-Bantani. These two organizations have been tirelessly campaigning for women's rights and promoting a new understanding of women's status in Islam. They have also been advocating legal issues concerning women's rights. When a bill contains potential discrimination against women was released by the parliament, Puan Amal Hayati, Rahima, and other similar organizations, came down to the roads, protesting it. Through brochures, leaflets, and other media, they campaign against polygamy, enforcement of wearing the veil, and the implementation of sharith in Indonesia.

Islamic feminist movement in its various expressions has gained some successes. In the early twentieth century, Qassim Ami was alone. Now, there are many Muslim scholars who would go with Amiæs arguments. Education for women is no longer a taboo issue. More and more Muslim women are unhesitatingly engaged in public sphere, as politicians, managers, workers, scientists, lawyers, and heads of state. Certainly, there are still some Muslim conservatives who rejected the idea of Islamic feminism. They entirely reject the Muslim reformists' agenda in reformulating Islamic doctrines on women. However, they only represent a small number of Muslims and are loosing their ground. In Indonesia, anti-Islamic feminism is conducted by the radical groups such as the Islamic Defenders Front (FPI, Front Pembela Islam), the Indonesian Council of Mujahidin (MMI, Majelis Mujahidin Indonesia), and Hizbut Tahrir Indonesia (HTI). Most of them are ignorant of the history of Islamic thought so that they fail to follow the development of Islamic discourse on women. 
The issue of women in Islam is certainly multidimensional. Certain issues developed in Islamic discourse of women's rights are still unacceptable, such as the issue of female ima in mix prayer. However, the fact that there are some Muslims practicing and discussing them is an indication that it is not beyond question. Other issues such as polygamy and female head-of-state are growingly contested. In Indonesia, although most Muslims do not dare to say that Islam is against polygamy, they are certainly embarrassed to accept it as a normal value. A good case-in-point is the negative response of Indonesian Muslims towards Abdullah Gymnastiar, a religious cleric (kiai) and a popular televangelist, who got married for the second time several months ago. ${ }^{15}$ The news of his second-marriage sent a big shock wave among Indonesian Muslims. Many of them expressed their disagreement to what the kiai has done. The negative response was widely demonstrated by leaving Gymnastiar's multi-billion religious programs and businesses. Reports said that six months after this scandal, Gymnastiar's businesses dramatically decreased. His business's revenue dropped more than $40 \%$ and his media fortune is threatened to collapse. ${ }^{16}$ Many progressive Muslims are happy finding that the sanity of Indonesian Muslims is considerably working.

\section{Religious Freedom}

Religious Freedom is relatively a new issue. Early Muslim reformists rarely discussed it, most probably because there were occupied by more important issues, such as colonialism, nationalism, and Muslim backwardness. Besides, before the end of the Second World War, most of Muslim countries were still under colonial dominion, where issues of religious freedom were solved by the colonial rule. After independence, however, religious freedom became a serious problem, mainly because it is immediately related to the constitution, civil liberty, and human rights. Almost all majority Muslim countries experienced uneasy debates around the role and the status of religion in the state. There were often two groups of them: those who supported the idea that Islam should play a greater role in the state and those who rejected it. Issues of religious freedom that

15 “Aa Gym Mengaku Nikahi Janda Beranak Tiga," Kompas, 2 December 2006; "Isu Nikahi Janda: Aa Gym Langsung Gelar Jumpa Pers,” Kompas, 2 December 2006.

16 “Pengajian Aa Gym Mulai Sepi,” Kompas, 8 December 2006. 
emerged in the post-colonial Muslim countries often generated from this early problem of state formation.

Theoretically speaking, Islam has two different views of religious freedom that can be diametrically opposite one to another. The first view says that Islam does not comply with many issues of religious freedom. Islam cannot tolerate the idea of religious conversion from Islam to other religions. It is simply considered apostate (riddah) whose sanction is no less than death penalty. According to this view, Islam is a superior religion that cannot be superseded by other religions ( $y a^{\prime} l u>$

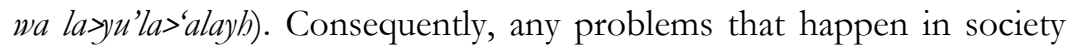
must be solved in Islamic ways. On the other hand, the second view believes that Islam is totally a tolerant and progressive religion, which does not force people to embrace their faith. It argues that the very scripture of Islam, the Qur'aæ, starkly says that "let there be no compulsion in religion" (Q.S. 2:256) and "for you is your religion and for me is mine" (Q.S. 109:6). Therefore, Islam is compatible with religious freedom.

The problem is certainly not in theory, but in practice. Since independence, religious freedom became a crucial problem of many Muslim countries, from Egypt to Indonesia, from yesteryear till today. Cases of religious freedom generally took place in the form of persecution of the majority against the minority, either Muslims against adherents of other religions or the followers of mainstream Sunni against the followers of minority groups such as Shi'ism, Baha'ism, and Ahmadiyah. In Egypt, the Christians often became the target of discrimination. In late 1999, 21 Christians in al-Kosheh were brutally murdered by Muslim extremists. Despite assurance from the government, there was no trial of this case. ${ }^{17}$ In April 2006, three churches in Alexandria were attacked by a Muslim, resulting in the death of one Christian and the wounding of a dozen others. Several days later, 59 Muslims were arrested for setting fire to Christian homes. There have been no prosecutions yet in these cases. In early 2001, 18 Egyptian Baha'is were arrested by the police on suspicion of insulting religion. Although Baha'ism is not a sect of Islam, religious authorities in Egypt keep suspecting that its followers are striving to debilitate Islam.

\footnotetext{
17 The Bureau of Democracy, Human Rights, and Labor, U.S. Department of State, "International Religious Freedom Report 2006: Pakistan.” See also 2007 report.
} 
In Pakistan, cases of religious freedom mostly befell on Islamic minority groups, particularly Ahmadiyah. Majority of Pakistanis are Sunni Muslims (77\%). Minorities comprise of the Shi'ites (19\%), Hindus $(1.5 \%)$, Christians (1\%), and Ahmadis $(0.2 \%)$. There are some cases that befell on the Shi'ites, the Christians, as well as the Hindus. They are however very small compared to what the Ahmadiyah members have suffered. Ahmadiyah is a sect of Islam founded by Mirza Ghulam Ahmad (d. 1908), an Indian Muslim reformer, in 1889. The central teaching of Ahmadiyah is a belief that Mirza Ghulam Ahmad is a prophet. This belief is against the doctrine of the Sunni majority that believes in the finality of the Prophet Muhammad. Pakistan's constitution requires that laws be consistent with Islam, i.e. with the Sunni majority, which considers Ahmadiyah as a deviant sect. Persecutions against Ahmadiyah resulted from this blemish constitution. Between 1984 to 1999, there were 45 Ahmadi members killed, 81 injured, 19 bodies were exhumed after burial in the cemetery, 31 were denied for burial, 66 Ahmadi mosques were demolished or set on fire. ${ }^{18}$

In Indonesia, Ahmadiyah also becomes the target of discrimination by the Muslim majority. Although Ahmadiyah members have existed in the country since quite long times (early 1920s), majority Sunni Muslims hardly accept the group. The membership of Ahmadiyah is not many. According to J.H. Lamardi, a leader of Ahmadiyah in Jakarta, the number of Ahmadis does not exceed half a million members. ${ }^{19}$ Like majority Muslims in Pakistan, the attitude of Indonesian Muslims towards Ahmadiyah members is hostile or at best intolerant. The highest authority of Indonesian Islam, the Indonesian Council of Ulama (MUI, Majelis Ulama Indonesia), has issued two fatwas on Ahmadiyah, where it condemns the sect to be "a deviant and deviating" (sesat dan menyesatkan). This fatwa greatly contributed to the violence against Ahmadiyah members. In late 2006, the Indonesian Human Rights Commission (Komnas HAM), issued an investigative report disclosing the role of the MUI's fatwas in shaping intolerant and

\footnotetext{
18 The Bureau of Democracy, Human Rights, and Labor, U.S. Department of State, "International Religious Freedom Report 2006: Indonesia." See also 2007 report.

${ }^{19}$ Interview with J.H. Lamardi, 21 May 2007.
} 
violent attitudes of Indonesian Muslims against Ahmadiyah members. ${ }^{20}$

In Malaysia, cases of religious freedom took place mostly on the non-Muslim minorities, particularly the Hindus and the Christians. Islam is the majority religion in Malaysia (61\%), although other religions comprise a great number of followers. Buddhism has $19 \%$ of followers, Christianity $9 \%$, and Hinduism 7\%. Since the last five years, religious freedom in Malaysia is increasingly getting worse. Ironically, this happened along with the government's campaign of "Civil Islam" (Islam Hadhar), which is supposed to maintain tolerance and religious harmony. In March 2007, R. Subashini, a Hindu woman whose husband converted to Islam, failed to get a divorce from the Civil Court and was forced to proceed to the Sharia Court, a decision that was against Malaysian Constitution, which clearly states that nonMuslims should be proceeded in Federal Court. In April, an Islamic authority raided the house of a Hindu man and his Muslim wife. It forced them to separate and took their 3-year-old daughter to prevent her from being converted to Hinduism. ${ }^{21}$ Christians, have also suffered from religious discrimination. The most widely-covered example is the case of Lina Joy, a Muslim woman converted to Christianity. Her case arouses a big shock in the country as she was threatened by apostasy charge. According to Muslim belief, an apostate is charged with death penalty.

Religious freedom is a crucial problem in the contemporary Muslim societies. Many problems aroused not from the Qur'anic doctrines as the scripture is quite clear on the issue, as I stated earlier. The problem comes from interpretations made by religious scholars (ulama $>$ either on particular ambiguous verses in the Qur'a or on the tradition of the Prophets (sunnah). The problem even becomes worst when such interpretations were adopted by the state or religious authority backed by the state. There is no short cut to remedy this problem. Tireless campaign and constant promotion of Islam and pluralism are the only option that is apparently viable now. In Indonesia, campaign and promotion of pluralist and tolerant values of

20 The National Commission of the Indonesian Human Rights (Komnas-HAM), "Ringkasan Eksekutif Pemantauan Kasus Ahmadiyah" (Jakarta, September 2006).

21 The Beureau of Democracy, Human Rights, and Labor, U.S. Department of State, "International Religious Freedom Report 2007: Malaysia." 
Islam have been undertaken by progressive groups such as the International Centre of Islam and Pluralism (ICIP), the Wahid Institute, the International Conference of Religion and Peace (ICRP), and the Liberal Islam Network (JIL). ICIP, an organization led by a liberal Muslim scholar, M. Syafii Anwar, has a special project promoting Islam and pluralism in pesantrens in Indonesia. The Wahid Institute and JIL, on the other hand, have been in the front line in the battle against persecution and discrimination of the majority against the minority groups in the country.

\section{Freedom of Expression}

Like the issue of religious freedom, freedom of expression is relatively a new item in Islamic discourse. It is part of the bigger issue, namely civil liberties, which include freedom of association, freedom of assembly, freedom of religion, and freedom of speech. Freedom of expression is a broader term for freedom of speech. In one sense, freedom of expression also includes the freedom of association and assembly since the ultimate target of forming an association is to express interests (be it political, economical, cultural, or any other interests) through congregation. Freedom of expression is entirely a Western discourse. There is no such an issue in the classical Islamic thought. Muslim philosophers and theologians discussed freedom in the context of god-human relationship and not human-human relationship. Thus, the discourse that was developed was around freewill and predeterminism. The idea that human being is free to express his or her opinion was totally out of question.

There are however circumstances that we may consider them as "cases of freedom of expression." The book burnings, the killing of an author, the torturing of a believer, are examples of the case of freedom of expression in the classical times. In $827 \mathrm{AD}$, al-Ma'muæ, the seventh 'Abbasid Caliph who believed in the Mu'tazilite doctrine, founded an institution of inquisition to question any Muslims who did not believe in the createdness of the Qur'aæ, a belief that was adopted by the Mu'tazilism. Some Muslims were afraid to face the torture from alMa'muæ, and some other dare to express their objection. Those who dare to express their opinion would face torture and severe sanction. Many cases of freedom of expression befell on politicians, philosophers, Sufis, and authors. Great Sufis such as al-H\{llapand Shiha $\$$ al-Diæ al-Suhrawardi $>$ were executed for their unorthodox 
views; Ibn Rushd was exiled and his books were burnt. The cases of different expressions -i.e. beliefs and opinions that were expressed differently from the one maintained by the status quo- were carried on either by the rulers or by religious authorities, or most of the time by both. There was absolutely no question why a person should be charged for what he or she believed.

With the absence of the discourse of freedom of expression in the classical Islamic thought, it is generally understandable if Muslim communities in the modern times find a great difficulty in dealing with the issues. There are many classical doctrines of Islam that are starkly incompatible with the modern spirit of freedom of expression. Take for example the doctrine of blasphemy, which can be applied to various actions, from visualizing the prophet, insulting the Qur'a or derogating Islamic teachings. The charge of blasphemy can also be applied to any Muslims who try to make a new understanding of Islam, in spite of the fact that they have a strong basis in Islamic theology. This often befalls on Muslim intellectuals who want to reform Islamic doctrines. In Egypt cases of blasphemy have become a common issue that befalls on authors and Muslim reformists. In 1995, Nasł $\mathrm{H}\{$ \{rid Abu Zayd, a prolific Muslim scholar, was brought to court for his book on the Qur'aæ. After some trials, he was declared heretic (murtad) and was forced to divorce his wife, as he was no longer considered as a Muslim. In 2001, Nawa $\triangleright S a$ 'dawi, $>a$ renowned novelist and a Muslim feminist, was brought to court for her statement about Islam in an interview in an Egyptian newspaper. She was forced, again, to end her 37-year-old marriage on the accusation that she is no longer a Muslim.

In Indonesia, cases of freedom of expression emerged in the public debate since 1950s. Among the most widely covered case was the publication of a short story written by $\mathrm{Ki}$ Panjikusmin, an anonymous writer, in August 1968. The novel, titled Langit Makin Mendung (The Darkening Sky), was protested by many Muslim leaders and was accused to have insulted God, Islam, and the Prophet Muhłmmad. The case was then brought to the court and the chief editor of the magazine that published the story, Hans Begue Jassin (himself was a great author), was sentenced to jail..22 In April 1991,

\footnotetext{
${ }^{22}$ Nanang Tahqiq, "Freedom of Speech and Literary Expression: A Case Study of 'Langit Makin Mendung' by Ki Pandjikusmin" (Unpublished MA Thesis, McGill University, Canada, 1995).
} 
Arswendo Atmowiloto, a young newspaper editor, was sentenced to five years in jail, for a charging of insulting Islam. What Atmowiloto did was actually just doing polling of leaders admired by his tabloid's readers. His "mistake" is to publish the result that in the polling the name of Prophet Muh łmmad was placed in the $11^{\text {th }}$. Indonesian Muslims considered it as blasphemous. The last case concerning the problem of Islam and freedom of expression took place in late 2002, when Ulil Abshar-Abdalla, a young Muslim writer, was condemned to death by a group of Muslim cleric in Bandung, West Java. AbsharAbdalla was accused to have insulted Islam in his article published in Kompas on 18 November that year. The article entitled "Freshening up the Islamic Understanding" was actually a short message for Muslims to rethink some of Islamic doctrines, which according to him have been obsolete. Abshar-Abdalla's case was never brought to court but his life was put in danger, as there were some attempts for Muslim radicals to murder him.

The most popular and high-profile case of Islam and of the freedom of expression is certainly that of Salman Rushdie, the British author of Indian origin. In February 1989, Ayatullah Khomeini, the leader of Islamic revolution in Iran, proclaimed a fatwa requiring Rushdie's death. Khomeini considered Rushdie's novel, the Satanic Verses, as against Islam and the Prophet Muhłmmad. The fatwa immediately aroused a fiery reaction by Muslims all over the world. In Berkeley, several bookstores selling Rushdie's book were firebombed. In Bombay, 5 people died in a protest at the British Embassy. Several other people died in various Muslim countries in rallies at the British and American Embassy. In 1991, Rushdie's Japanese translator, Hitoshi Igarishi, was killed in Tokyo, and his Italian translator was stabbed in Milan. Rushdie's affair was perhaps the hottest case of Islam and freedom of expression in the modern history. ${ }^{23}$ Muslims seemed to have never forgiven Rushdie as eighteenth years later, a series of rally against Rushdie were orchestrated in some Muslim countries. This time was a protest against an award of knighthood given to the author. The protest took place only a year after the

\footnotetext{
${ }^{23}$ Dan Cohn-Sherbok, The Salman Rushdie Controversy in Interreligious Perspective (Lewiston: E. Mellen Press, 1990); M. M. Ahsan and A. R. Kidwai, Sacrilege Versus Civility: Muslim Perspectives on the Satanic Verses Affair (Markfield, Leicester, U.K.: Islamic Foundation, 1991).
} 
Muslims' rage to another controversial publication, i.e. the Danish Cartoon.

Apparently, there is nothing much that the Muslim reformists can do with regards to the issue of Islam and freedom of expression. Unless there is a radical approach in reformulating the doctrine of blasphemy that the Muslims can fully comply with the concept of freedom of expression. Unfortunately, majority of Muslims choose to maintain the old doctrine than to consider the positive values of freedom of expression. There are some Muslim countries like Turkey and Indonesia that do not recognize the law of blasphemy. However, the problem does not so much lie in the constitutional or legal texts, but rather in the mind and mentality of the Muslim majority. The charge of blasphemy is often started from the conservative Muslim clerics, who spread their ideas into lay Muslims. The government usually prefers to be silent witnessing a huge wave of Muslim protests demanding for blasphemy law. Thus, like in the case of religious freedom, the remedy has no short cut. It needs a persistent and long campaign to the Muslims that Islam is compatible with the freedom of expression. In turn, this requires a radical reinterpretation of some of the classical Islamic doctrines regarding the Prophet, the Qur'aæ and other intolerant teachings.

\section{Conclusion}

Islamic reform movement is a long and a risky task that the Muslim intellectuals have been striving for since the last two centuries. Starting from the Middle East, the movement spread all over the Muslim world. Since the beginning, the character of Islamic reform movement is liberal in the sense that it promotes progressive and enlightening ideas. In the early periods, the main agenda of Islamic reform movement was to question reasons that caused Muslims lagging behind and how to free themselves from the shackles of Western colonialism. In the latter periods, issues such as democracy, freedom, and pluralism, became predominant among Muslim scholars. There are four main agendas that the Muslim reformists have been trying to deal with, namely, the issue of Islamic polity, the issue of women's rights, religious freedom, and freedom of expression. As I have succinctly elaborated, Muslim reformists have gained some progress and some regress in dealing with those four issues. [] 


\section{Bibliography}

\section{Books and Articles}

Ahmed, Ishtiaq. The Concept of an Islamic State: An Analysis of the Ideological Controversy in Pakistan. London: Pinter, 1987.

Ahsan, M. M., and A. R. Kidwai. Sacrilege Versus Civility: Muslim Perspectives on the Satanic Verses Affair. Markfield, Leicester, U.K.: Islamic Foundation, 1991.

Ali, Chiragh. "Islam and Change," in John J. Donohue and John L. Esposito. Islam in Transition: Muslim Perspectives. New York: Oxford University Press, 1982.

Al-Jabarti>’Abd al-Rahinał. 'Ajaß al-A $1^{\text {st }}$ ed. Cairo: Lajnat al-Bayałal-'Arabi>1958.

Arslan, Amir Shakib. Lima $>$ Ta'akbkhar al-Muslimu»wa Lima $>$ Taqaddam Ghayrubum. Beirut: Maktabat al-H\{yał, 1975.

Cohn-Sherbok, Dan. The Salman Rushdie Controversy in Interreligious Perspective. Lewiston: E. Mellen Press, 1990.

Dobbin, Christine. "Islamic Revivalism in Minangkabau at the Turn of the Nineteenth Century." Modern Asian Studies, 8, No. 3, July 1974, 319-56.

Enayat, Hamid. Modern Islamic Political Thought. Kuala Lumpur: Islamic Book Trust, 2004.

Hamka. Ajabku, Riwajat Bidup Dr. H. Abd. Karim Amrullah Dan Perdjuangan Kaum Agama Di Sumatra. $2^{\text {nd }}$ ed. Djakarta: Widjaya, 1958.

Hanifah, Abu. Kedudukan Agama dalam Negara-Negara Modern dan Merdeka. [Jogjakarta]: Kementerian Agama R.I., 1948.

Hefner, Robert W. Civil Islam: Muslims and Democratization in Indonesia. Princeton N.J.: Princeton University Press, 2000

Hooker, Virginia Matheson. "Developing Islamic Argument for Change through 'Liberal Islam,", in Amin Saikal and Virginia Matheson Hooker. Islamic Perspectives on the New Millennium, Iseas Series on Islam. Singapore: Institute of Southeast Asian Studies, 2004.

Hourani, Albert. Arabic Thought in the Liberal Age, 1798-1939. Cambridge; New York: Cambridge University Press, 1983. 


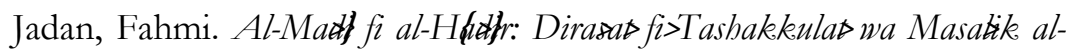
Tajriah al-Fikerizanh al-'Arabizah. Beirut: al-Mu'assasah al'Arabiparh li al-Dirasatwa al-Nashr, 1997.

------.. Usustal-Taqaddum 'inda Mufakekir al-Islamfi al-'Alkm al-'Arabi Hadd ‘Ammaæ. Daßal-Shuruథ, 1988.

Kurzman, Charles. Liberal Islam: A Source Book. New York: Oxford University Press, 1998.

Laffan, Michael Francis. Islamic Nationhood and Colonial Indonesia: The Umma Below the Winds, Soas/Routledgecurzon Studies on the Middle East. London; New York: RoutledgeCurzon, 2003.

Lewis, Bernard. The Middle East and the West. Bloomington,: Indiana University Press, 1964.

Madjid, Nurcholish and Mohamad Roem. Tidak Ada Negara Islam: Surat-Surat Politik Nurcholish Madjid-Mohamad Roem. Cet. 2. Jakarta: Djambatan, 2000.

Mawdudi, Abul-Ala. "Political Theory of Islam," in John J. Donohue and John L. Esposito. Islam in Transition: Muslim Perspectives. New York: Oxford University Press, 1982.

Muhammad, Husein. Figh Perempuan: Refleksi Kiai atas Wacana Agama dan Gender. Yogyakarta: LKiS and Rahima, 2002.

Noer, Deliar. The Modernist Muslim Movement in Indonesia, 1900-1942, East Asian Historical Monographs. New York: Oxford University Press, 1973.

Rahman, Fazlur. Islam \& Modernity: Transformation of an Intellectual Tradition, Chicago: University of Chicago Press, 1982.

Roff, William R. The Origins of Malay Nationalism, Yale Southeast Asia Studies. New Haven: Yale University Press, 1967.

Saeed, Abdullah, and Hassan Saeed. Freedom of Religion, Apostasy, and Islam. Aldershot, Hants, England; Burlington, VT: Ashgate, 2004.

Soroush, Abdolkarim. Reason, Freedom, and Democracy in Islam: Essential Writings of Abdolkarim Soroush. New York, N.Y.: Oxford University Press, 2000. 
Tahqiq, Nanang. "Freedom of Speech and Literary Expression: A Case Study of 'Langit Makin Mendung' by Ki Pandjikusmin." Unpublished MA Thesis, McGill University, Canada, 1995.

Tamimi, Azzam. Islam and Secularism in the Middle East. London: Hurst \& Co., 2000.

The National Commission of the Indonesian Human Rights (KomnasHAM). "Ringkasan Eksekutif Pemantauan Kasus Ahmadiyah." Jakarta, September 2006.

The Persecution Website. http://www.thepersecution.org/facts/events.html

US Commission on International Religious Freedom. "Briefing on Religious Freedom in Egypt: Recent Developments." 23 May 2007.

Vatikiotis, P. J. The History of Modern Egypt: From Mubammad Ali to Mubarak. 4th ed. Baltimore: Johns Hopkins University Press, 1991.

\section{Newspapers}

"Aa Gym Mengaku Nikahi Janda Beranak Tiga." Kompas, 2 December 2006.

"Isu Nikahi Janda: Aa Gym Langsung Gelar Jumpa Pers.” Kompas, 2 December 2006.

"Mujahidin tak Ingin Dirikan Negara Islam.” Kompas, 6 August 2000

"Pengaiian Aa Gym Mulai Sepi.” Kompas, 8 December 2006.

"Syariah Islam, Bukan Negara Islam." Tekad, No. 40, 7-13 August 2000.

“Tak Ada Lagi Negara Islam.” Panjimas, 9-16 August 2000. 